\title{
Peran Persepsi Siswa atas Keterampilan Sosial-Emosional Guru terhadap Regulasi Emosi Siswa Sekolah Inklusi
}

\author{
Putri Rahmawati ${ }^{1} \&$ Edilburga Wulan Saptandari ${ }^{2}$ \\ 1,2 Fakultas Psikologi Universitas Gadjah Mada \\ Jl. Sosio Humaniora Bulaksumur, Karang Malang, Caturtunggal, Kec. Depok, Kabupaten Sleman, \\ Daerah Istimewa Yogyakarta 55281; (0274) 550435 \\ Email : ${ }^{1}$ putri.r@mail.ugm.ac.id, ${ }^{2}$ ewulans@ugm.ac.id
}

Received: $17^{\text {th }}$ September 2020/ Revised: $16^{\text {th }}$ December 2020/ Accepted: $2^{\text {th }}$ December 2020

\begin{abstract}
Emotion Regulation is important for student social interactions. Inclusive school that facilitate diversity can increase the student conflict. Conflict occurs because of the lack of skill in managing emotion. Therefore, the teacher has a task to support the development of student emotional regulation. The purpose of this study was to empirically examine the role of teacher social-emotional skills on emotional regulation in students at inclusive schools. The participants of this study were 109 students aged 9-13 years from three different inclusive schools at Yogyakarta. The method that used is survey by directly distributing the scale. Student perception about teacher social-emotional skills was measured by Teacher Social and Emotional Practice - Student Perspectives, while emotion regulation is measured with emotion regulation scale. Simple linear regression analysis is used to measure the role of teacher social-emotional skills on emotion regulation. The results showed that student perception about teacher social-emotional skills play a positive role on emotion regulation in students at inclusive schools. The higher student perception about teachers' social-emotional skill the higher students' emotion regulation.
\end{abstract}

Keyword: emotion regulation, inclusive school, student perception of teachers social-emotional skills

\begin{abstract}
Abstrak. Regulasi emosi merupakan hal yang penting dalam interaksi sosial siswa. Sekolah inklusi yang memfasilitasi keberagaman dapat meningkatkan terjadinya konflik antar siswa. Konflik terjadi karena kurangnya keterampilan dalam mengatur emosi. Oleh karena itu guru memiliki tugas dalam mendukung perkembangan regulasi emosi siswa. Tujuan dari penelitian ini adalah untuk menguji secara empirik peran persepsi siswa atas keterampilan sosial-emosional guru terhadap regulasi emosi siswa sekolah inklusi. Partisipan penelitian ini adalah 109 siswa dengan rentang usia 9-13 tahun dari tiga sekolah dasar inklusi di Kota Yogyakarta. Metode yang digunakan yaitu survei dengan menyebarkan skala secara langsung. Persepsi siswa atas keterampilan sosial-emosional guru diukur dengan Teacher Social and Emotional Practice - Student Perspective, sedangkan regulasi emosi diukur dengan skala regulasi emosi. Analisis regresi linear sederhana digunakan untuk mengukur peran persepsi siswa atas keterampilan sosial-emosional guru terhadap regulasi emosi. Hasil pada penelitian ini menunjukkan bahwa persepsi siswa atas keterampilan sosial-emosional guru memiliki peran yang positif terhadap regulasi emosi siswa sekolah inklusi. Ketika siswa mempersepsikan guru memiliki keterampilan sosial-emosional yang tinggi maka regulasi emosi siswa juga cenderung akan tinggi.
\end{abstract} Kata kunci: persepsi siswa atas keterampilan sosial-emosional guru, regulasi emosi, sekolah inklusi

Kota Yogyakarta bertekad mewujudkan

diri sebagai kota inklusi. Sulistyo, seorang pejabat pelaksana tugas walikota Yogyakarta

pada saat program kota inklusi, memaparkan 
bahwa kota inklusi artinya kota yang tidak ada diskriminasi, tidak ada yang dibedabedakan, dan semua fasilitas bisa dimanfaatkan bersama (Utantoro, 2016). Hal yang mendasari upaya mewujudkan Yogyakarta sebagai kota inklusi adalah adanya Peraturan Daerah DIY Nomor 4 Tahun 2012 tentang Perlindungan dan Pemenuhan Hak Penyandang Disabilitas (Utantoro, 2016). Salah satu bidang yang sudah menerapkan konsep inklusi ialah bidang pendidikan dengan dasar Undangundang No.20 tahun 2003 tentang Sistem Pendidikan Nasional (Anonim, 2019). Hal tersebut yang menjadi cikal-bakal bagi Kota Yogyakarta untuk mewajibkan seluruh sekolah negeri menjadi sekolah inklusi.

Sekolah inklusi menerapkan sistem pendidikan yang mencakup semua siswa dan menyambut serta mendukung siswa untuk belajar tanpa memandang kemampuan atau persyaratan lain (UNICEF, 2017). Sekolah inklusi juga menciptakan lingkungan belajar yang memungkinkan siswa untuk mendapat manfaat dari pendekatan individu yang dilakukan (Chan \& Yuen, 2015). Prinsip dasar dari sekolah inklusi yaitu mengusahakan semua siswa harus belajar bersama.

Sekolah inklusi menciptakan lingkungan yang memungkinkan tiap individu dari berbagai latar belakang untuk secara efektif bekerja sama dan menunjukkan potensinya untuk mencapai tujuan bersama (Budiarti \& Sugito, 2018) Sekolah juga sadar dan tanggap dengan memberi dukungan dan fasilitas untuk memenuhi kebutuhan siswa (Armstrong, 2008). Maka dapat disimpulkan bahwa sekolah inklusi ialah sekolah yang menerima keberagaman siswa dengan memberi fasilitas dan dukungan untuk memenuhi kebutuhan masing-masing siswa demi terciptanya hasil yang optimal.

Nilai keberagaman di sekolah inklusi ditunjukkan dengan kesediaan sekolah untuk menerima siswa yang berasal dari berbagai latar belakang budaya, agama, suku, adat, status ekonomi, dan kebutuhan. Menurut Pelled, Eisenhardt, dan Xin (1999) keberagaman dalam kelompok dapat meningkatkan konflik emosional. Hal tersebut terjadi karena adanya keanekaragaman yang kompleks sehingga muncul stereotipe dan mengarah pada konflik emosional. Konflik emosional dijelaskan sebagai kondisi ketika individu memiliki masalah antar pribadi yang ditandai dengan agresi, frustasi, dan perasaan negatif lainnya (Pelled dkk., 1999). Kelsey, Zeman, dan Dallaire (2017) menjelaskan bahwa perilaku agresi biasa dikaitkan dengan kurangnya 
keterampilan regulasi emosi. Santrock (2015) juga menyatakan bahwa regulasi emosi berperan penting dalam keterampilan seseorang untuk mengelola tuntutan dan konflik yang dihadapi saat berinteraksi dengan orang lain.

Bowie (2010) melakukan penelitian tentang hubungan antara regulasi emosi dan agresi lalu menemukan bahwa keterampilan regulasi emosi yang rendah pada anak usia 51/2 sampai 12 tahun dapat memprediksi perilaku agresi dua tahun kemudian. Callear, Harvey, dan Bimler (2017) juga menyatakan bahwa kesulitan regulasi emosi juga berkaitan dengan gangguan perilaku, kecemasan, dan mood pada masa pra remaja. Selain itu, individu dengan kesulitan regulasi emosi juga berkaitan dengan kecenderungan untuk melakukan kegiatan yang tidak bermanfaat seperti menyalahkan diri sendiri, menghambat ekspresi emosi, dan penyangkalan atas suatu kejadian (Karababa, 2020). Hal tersebut membuktikan bahwa keterampilan regulasi emosi merupakan salah satu hal yang perlu ditingkatkan pada usia sekolah dasar.

Keterampilan regulasi emosi dianggap sebagai hal yang penting untuk keberhasilan seseorang saat berinteraksi dengan orang lain dalam berbagai seting termasuk di rumah, sekolah, atau tempat kerja (Macklem, 2008). Regulasi emosi dijelaskan sebagai proses individu dalam memahami emosi yang dirasakan serta mengetahui kapan emosi tersebut terjadi dan bagaimana ia mengalami atau mengekspresikan emosinya (Gross, 2014). Selain itu, regulasi emosi juga terjadi untuk membantu individu mengelola emosi yang dirasakan dengan strategi yang melibatkan perilaku, hubungan interpersonal, pengalaman, dan kognitif (Callear et al., 2017). Maka dapat disimpulkan bahwa regulasi emosi merupakan proses individu dalam memahami dan mengelola emosi yang dirasakan, serta cara individu untuk mengekspresikan emosinya dengan melibatkan pengalaman, dan perilaku. Regulasi emosi siswa sekolah inklusi berperan dalam proses individu untuk mengenali dan mengekspresikan emosinya atas keberagamanan latar belakang sosial, ekonomi, suku, agama dan kemampuan temannya yang ada di sekolah. Semakin beragam suatu kelompok maka akan menciptakan konflik emosi yang lebih tinggi. Siswa perlu untuk belajar mengatur emosinya supaya tidak menciptakan konflik yang dapat merugikan diri dan lingkungan sekitar.

Menurut Graziano, Reavis, Keane, dan Calkins (2007) keterampilan regulasi emosi 
yang baik pada anak ditunjukkan dengan adanya keterampilan sosial, kompetensi sosial dan popularitas pada teman sebaya yang lebih baik. Siswa yang terampil dan kompeten secara sosial akan menunjukkan perilaku yang positif. Siswa menunjukkan perilaku saling menghargai, membantu, dan dapat menangani situasi konflik dengan baik. Siswa di sekolah inklusi yang terampil dan kompeten secara sosial akan menunjukkan perilaku yang positif terhadap temannya. Selain itu, Gross (2014) juga menjelaskan bahwa regulasi emosi berkaitan dengan tingkat well being, kesehatan mental, fungsi kognitif, dan hubungan sosial seseorang.

Perkembangan regulasi emosi terjadi sejak anak sudah mulai mengenal emosinya. Keluarga dianggap sebagai orang pertama yang bertugas mengajarkan anak tentang cara meregulasi emosi. Namun ketika anak sudah mulai bersekolah maka waktu interaksi antara anak dan keluarga akan cenderung berkurang. Anak akan lebih banyak menghabiskan waktunya di sekolah. Menurut Jennings dan Greenberg (2009) keterampilan sosial-emosional guru berperan dalam peningkatkan regulasi emosi siswa. Guru adalah sumber keamanan emosional dan memiliki pengaruh penting pada perkembangan regulasi emosi siswa
(Saptandari, 2019). Guru juga dianggap memiliki kontribusi yang sangat penting pada perkembangan sosial dan emosional siswa yang akan berpengaruh pada kehidupan siswa hingga dewasa (Jennings \& Greenberg, 2009).

Saptandari (2019) menjelaskan bahwa guru merupakan role model yang berperan kuat dalam membentuk pembelajaran dan perkembangan akademik, sosial, emosional, dan spiritual siswa. Siswa pada jenjang sekolah dasar masih bergantung pada orang dewasa. Guru sebagai orang dewasa dan seseorang yang menghabiskan sekitar enam jam dalam sehari untuk berinteraksi dengan siswa dianggap sebagai salah satu orang yang dipercaya oleh siswa. Ketika siswa percaya dengan guru, maka siswa akan cenderung memiliki hubungan yang baik dengan guru. Hubungan yang baik tersebut mengarah pada perilaku menghormati dan menghargai guru sehingga siswa cenderung akan mencontoh dan mengikuti instruksi yang diberikan guru.

Guru dengan keterampilan sosialemosional memiliki tingkat kesadaran diri atau self awareness yang tinggi (Jennings \& Greenberg, 2009). Menurut kedua peneliti ini, guru dengan keterampilan sosial-emosional mampu mengenali emosi, pola emosi, dan mengetahui bagaimana cara menggunakan 
emosi untuk memotivasi kegiatan belajar pada dirinya dan orang lain. Guru yang terbiasa melibatkan aspek emosi dalam pembelajaran cenderung lebih diperhatikan siswa. Hal tersebut terjadi karena pendekatan dengan menggunakan aspek emosi lebih terinternalisasi pada diri siswa sehingga pencapaian akademiknya juga lebih baik. Harvey dkk., (2012) mengungkapkan bahwa pendekatan emosional yang dilakukan oleh guru dapat mengembangkan iklim emosi yang positif pada siswa. Penelitian tersebut menjelaskan bahwa emosi guru sangat berperan penting untuk meningkatkan kesejahteraan emosional siswa dalam konteks kelas. Guru dapat mengatur emosinya untuk merubah emosi siswa yang akhirnya berpengaruh pada iklim emosional di kelas.

Guru dengan keterampilan sosialemosional juga memiliki kesadaran sosial atau social awareness yang tinggi (Jennings \& Greenberg, 2009). Guru tahu bagaimana ekspresi emosi mereka mempengaruhi interaksi dengan orang lain (Jennings \& Greenberg, 2009). Denham, Bassett, dan Zinsser (2012) menjelaskan bahwa respon emosi positif guru pada siswa memiliki kaitan dengan ekspresi emosi siswa dan keterampilan regulasi emosinya. Siswa yang merasa gurunya memberi respon positif akan berdampak pada perilaku menghormati guru. Hal tersebut terjadi karena siswa merasa dibimbing oleh guru dengan cara yang tepat sehingga siswa akan memberi tangapan dan dukungan atas apa yang dilakukan guru.

Hasil penelitian yang mendukung peneliti untuk melakukan penelitian ini dijelaskan oleh Breeman dkk. (2015). Pada penelitian tersebut ditemukan bahwa keterampilan emosional yang dimiliki siswa merupakan hasil dari adanya penilaian yang positif terhadap gurunya. Selain itu, Jennings dan Greenberg (2009) juga menjelaskan bahwa keterampilan sosial-emosional guru dalam aktivitas belajar mengajar di kelas merupakan hal yang penting untuk perkembangan akademik, sosial, dan emosional anak.

Namun dalam penelitian yang dilakukan oleh Breeman dkk. (2015) serta Jennings dan Greenberg (2009) tersebut belum secara spesifik menjelaskan tentang peran persepsi siswa atas keterampilan sosial-emosional guru terhadap regulasi emosi siswa. Lebih jauh lagi, penelitian mengenai persepsi siswa atas keterampilan sosial-emosional guru dan regulasi emosi siswa belum banyak dilakukan dalam konteks Indonesia. Maka, peneliti memilih variabel regulasi emosi sebagai variabel yang dipengaruhi oleh persepsi siswa 
atas keterampilan sosial-emosional guru. Selain itu, peneliti juga melakukan penelitian pada seting sekolah inklusi yang belum banyak dilakukan oleh penelitian terdahulu.

Berdasarkan latar belakang tersebut maka penelitian ini bertujuan untuk mengetahui peran persepsi siswa atas keterampilan sosialemosional guru terhadap regulasi emosi siswa sekolah inklusi. Rumusan masalah yang diajukan dalam penelitian ini yaitu "Apakah ada peran positif dari persepsi siswa atas keterampilan sosial-emosional guru terhadap regulasi emosi siswa sekolah inklusi?". Hipotesis penelitian yang diajukan yaitu terdapat peran yang positif dari persepsi siswa atas keterampilan sosial-emosional guru terhadap regulasi emosi siswa sekolah inklusi.

\section{Metode}

\section{Partisipan Penelitian}

Pengambilan sampel ini dilakukan dengan teknik convenience sampling yaitu bahwa peneliti memilih partisipan karena mereka mau dan bersedia untuk menjadi subjek penelitian (Creswell, 2012). Populasi partisipan pada penelitian ini yaitu siswa sekolah inklusi di Yogyakarta. Partisipan berasal dari tiga sekolah dasar negeri yang berstatus inklusi di Kota Yogyakarta. Sampel partisipan yang dipilih yaitu siswa di sekolah inklusi yang secara kognitif mampu untuk mengisi, memahami, dan mengikuti proses jalannya penelitian sehingga siswa dengan masalah kognitif yaitu memiliki IQ dibawah 80 tidak disertakan dalam tahap analisis. Partisipan pada penelitian ini berjumlah 109 orang dengan rentang usia 9-13 tahun (M= 10.945, $\mathrm{SD}=0,979)$, perbandingan jenis kelamin yaitu perempuan 59\% dan laki-laki $41 \%$.

\section{Prosedur Penelitian}

Penelitian ini menggunakan metode survei atau penyebaran skala secara langsung. Skala pada penelitian ini menggunakan skala likert yang didesain dengan menyesuaikan karakteristik serta kemampuan pemahaman anak. Pada proses pengambilan data, partisipan diberi satu lembar kertas berukuran A3 sebagai lembar kerja, serta kumpulan kartu kecil berukuran $2 \mathrm{~cm}$ x $5 \mathrm{~cm}$ yang berisi aitem dari skala yang digunakan. Kumpulan kartu kecil tersebut terdiri atas 49 kartu yang mengukur persepsi siswa atas keterampilan sosial-emosional guru dan enam kartu mengukur regulasi emosi siswa.

Pengerjaan dilakukan secara individu oleh masing-masing siswa. Proses pengerjaan dilakukan dengan prosedur sorting. Pada 
tahap pertama, partisipan diminta untuk memberi respon dengan memilih satu diantara tiga pilihan jawaban (sesuai, tidak yakin, dan tidak sesuai untuk skala regulasi emosi; sering melihat, tidak yakin, dan jarang melihat untuk skala persepsi siswa atas keterampilan sosial-emosional guru) dan meletakkan kartu pada kolom pilihan jawaban yang sesuai pada lembar kerja yang telah disediakan. Setelah itu partisipan diminta untuk membaca ulang tiap aitem yang telah diletakkan dalam lembar kerja.

Pada setiap aitem yang dibacanya kembali, partisipan diminta untuk menentukan respon akhir terhadap masingmasing aitem dalam lima pilihan jawaban (sangat sesuai, cukup sesuai, tidak yakin, tidak terlalu sesuai, dan sama sekali tidak sesuai untuk skala regulasi emosi; sangat sering melihat, melihat tapi tidak terlalu sering, tidak yakin, pernah melihat, dan sama sekali tidak pernah melihat untuk skala persepsi siswa atas keterampilan sosialemosional guru). Jika partisipan berubah pikiran, ia boleh memindahkan kartu pada kolom pilihan jawaban lain setiap waktu.

Prosedur tersebut dilakukan untuk seluruh aitem. Ketika partisipan sudah selesai meletakkan semua kartu pada lembar kerja lalu partisipan diminta untuk memasukan tiap kartu kedalam amplop kecil yang sudah diberi kode. Pada lembar kerja sudah terdapat kode sehingga partisipan hanya diminta untuk menyesuaikan kode pada lembar kerja dan kode pada amplop lalu memasukannya. Apabila semua skala sudah selesai dikerjakan selanjutnya partisipan diminta untuk memasukan seluruh amplop berkode kedalam amplop besar yang sudah disediakan.

\section{Instrumen Penelitian}

\section{Skala Regulasi Emosi}

Skala regulasi emosi ini merupakan skala yang disusun oleh Wulandari (2018) berdasar teori strategi regulasi emosi oleh Gross (2014). Aspek yang ada dalam skala ini yaitu cognitive reappraisal dan expressive suppresion. Contoh aitem yang diberikan yaitu 'Aku tidak berani bertanya karena takut disalahkan guru', 'Aku takut akan kegagalan karena membuatku putus asa', 'Aku menangis karena merasa kecewa mendapat nilai ujian yang jelek'. Peneliti melakukan uji coba pada 14 aitem skala ini. Berdasarkan hasil uji coba lalu peneliti melakukan pengguguran aitem yang memiliki $r>0,25$. Berdasarkan hasil uji coba didapatkan 6 aitem yang sahih dengan koefisien reliabilitas alpha cronbach sebesar 0,79 . 
Skala Persepsi Siswa atas Keterampilan SosialEmosional Guru

Skala persepsi siswa atas keterampilan sosial-emosional guru ini disusun berdasar skala penelitian milik Saptandari (2019) yaitu Teachers' Social and Emotional Practices Students' Perspective (TSEP-SP). Skala ini terdiri atas tujuh aspek yaitu memprioritaskan pembelajaran, membangun hubungan, fokus untuk memotivasi dan mendukung, peduli, membimbing hubungan, sikap positif guru, dan pengaturan perilaku. Contoh aitem yang diberikan yaitu 'Guru mendorong siswa untuk membantu menjelaskan materi pelajaran kepada teman yang belum paham', 'Guru mendorong siswa untuk menolong teman yang memerlukan bantuan', 'Guru meminta siswa yang melakukan kesalahan untuk minta maaf'.

Peneliti melakukan uji coba pada 82 aitem skala ini. Berdasarkan hasil uji coba, peneliti melakukan pengguguran aitem yang memiliki $r<0,428$. Berdasarkan hasil uji coba pada skala ini didapatkan 49 aitem yang sahih dengan koefisien reliabilitas alpha cronbach sebesar 0,946.

\section{Analisis Data}

Metode analisis data pada penelitian ini menggunakan teknik regresi sederhana. Field
(2009) menjelaskan bahwa analisis regresi digunakan untuk memprediksi variabel hasil dari satu variabel prediktor (regresi sederhana) atau beberapa variabel prediktor (regresi berganda).

Menurut Hadi (2015) metode analisis regresi digunakan untuk menjelaskan arah dan besaran sumbangan variabel independen dalam memprediksi variabel dependen. Oleh karena itu pada penelitian ini, peneliti menggunakan analisis regresi sederhana untuk mengetahui peran antara variabel prediktor yaitu persepsi siswa atas keterampilan sosial-emosional guru terhadap regulasi emosi siswa. Selain itu peneliti juga melakukan uji normalitas dan uji linearitas sebelum melakukan analisis regresi.

\section{Hasil}

Rerata empirik variabel persepsi siswa atas keterampilan sosial-emosional guru adalah 200,56 $(\mathrm{SD}=25,571)$ dan rerata hipotetik adalah $147(\mathrm{SD}=32,66)$. Sedangkan rerata empirik untuk variabel regulasi emosi adalah $21,633(\mathrm{SD}=4,86)$ dan rerata hipotetik adalah $18(\mathrm{SD}=4)$. Kategorisasi data pada penelitian ini menunjukkan bahwa siswa yang mempersepsikan keterampilan sosialemosional guru pada kategori rendah berjumlah 16 orang, sedang 77 orang, dan 


\section{RAHMAWATI \& SAPTANDARI}

tinggi 16 orang. Sedangkan, siswa dengan regulasi emosi yang rendah berjumlah 15 orang, sedang 73 orang, dan tinggi 21 orang.

Hipotesis dalam penelitian ini adalah persepsi siswa atas keterampilan sosialemosional guru memiliki peran yang positif terhadap regulasi emosi. Sebelum melakukan uji hipotesis, peneliti melakukan uji asumsi yaitu uji normalitas dan uji linearitas. Berdasar hasil uji normalitas dengan onesample kolmogorov-smirnov test terlihat bahwa data berdistribusi normal dengan taraf signifikansi $\mathrm{p}>0,05$ (lihat Tabel 1).

Tabel 1.

Hasil Uji Normalitas

\begin{tabular}{ccc}
\hline Variabel & KS-Z & p \\
\hline Persepsi siswa atas & 0,038 & 0,200 \\
keterampilan sosial- & & \\
emosional guru dan \\
regulasi emosi
\end{tabular}

\section{Tabel 2.}

Hasil Uji Linearitas

\begin{tabular}{ccccc}
\hline Variabel & $\begin{array}{c}\mathbf{F} \\
\text { Lineari } \\
\text { ty }\end{array}$ & $\mathbf{p}$ & $\begin{array}{c}\text { F- } \\
\text { Deviatio } \\
\mathbf{n} \text { from } \\
\text { Linearity }\end{array}$ & $\mathbf{p}$ \\
\hline Persepsi & 32,572 & 0,000 & 0,949 & 0,581 \\
siswa atas & & & & \\
keterampi- & & & & \\
lan sosial- & & & & \\
emosional & & & & \\
guru dan & & & & \\
regulasi & & & & \\
emosi & & & & \\
\hline
\end{tabular}

Selain itu, berdasarkan hasil uji linearitas maka didapatkan hasil yang ditunjukkan dengan skor linearity F $(1,107)=$ 32.572, $\mathrm{p}<0.05$. Serta skor deviation from linearity $\mathrm{F}(1,107)=0.949, \mathrm{p}>0.05$ (lihat Tabel 2). Hasil tersebut menjelaskan bahwa persepsi siswa atas keterampilan sosial-emosional guru memiliki hubungan yang linear dengan regulasi emosi.

Setelah dilakukan uji normalitas dan uji linearitas maka selanjutnya dilakukan uji hipotesis dengan menggunakan teknik analisis regresi linear sederhana. Berdasarkan hasil yang diperoleh, diketahui bahwa hipotesis peneliti diterima dengan skor $\mathrm{F}=$ 33,595 pada taraf signifikansi $\mathrm{p}<0,05$. Hasil tersebut dapat dlihat pada Tabel 3. Selain itu, hasil analis juga menunjukkan bahwa persepsi siswa atas keterampilan sosialemosional guru memberi sumbangan efektif sebesar $23,9 \%$ terhadap regulasi emosi $\left(R^{2}=\right.$ $0,239)$.

Tabel 3.

Hasil Analisis Regresi Linear Sederhana

\begin{tabular}{ccccc}
\hline Variabel & $\mathbf{R}$ & $\boldsymbol{R}^{\mathbf{2}}$ & $\mathbf{F}$ & $\mathbf{p}$ \\
\hline $\begin{array}{l}\text { Persepsi siswa } \\
\text { atas }\end{array}$ & 0,489 & 0,239 & 33,595 & 0,000 \\
keterampilan & & & & \\
$\quad$ sosial- & & & & \\
emosional & & & & \\
$\quad$ guru * & & & & \\
regulasi emosi & & & & \\
\hline
\end{tabular}

Koefisien regresi dari variabel persepsi siswa atas keterampilan sosial-emosional 
guru bernilai positif. Hal tersebut dapat dilihat pada Tabel 4. Nilai $\beta$ sebesar 0,093 dengan taraf signifikan $p<0,05$ yang menunjukkan bahwa persepsi siswa atas keterampilan sosial-emosional guru memiliki peran positif yang signifikan terhadap regulasi emosi. Semakin tinggi persepsi siswa atas keterampilan sosial emosional guru maka semakin tinggi pula regulasi emosi siswa, dan sebaliknya.

\section{Tabel 4.}

Hasil Koefisien Regresi Variabel Persepsi Siswa atas Keterampilan Sosial-Emosional guru

\begin{tabular}{lcccc}
\hline & $\begin{array}{c}\text { Unstan } \\
\text { darized } \\
\text { coeffi- } \\
\text { cients } \\
(\boldsymbol{\beta})\end{array}$ & $\begin{array}{c}\text { Standa } \\
\text { rized } \\
\text { coeffi- } \\
\text { cients } \\
(\boldsymbol{\beta})\end{array}$ & $\mathbf{t}$ & $\begin{array}{c}\text { Sig. } \\
(\mathbf{p})\end{array}$ \\
\hline Konstanta & 2,999 & 3,241 & 0,925 & 0,357 \\
$\begin{array}{l}\text { Persepsi } \\
\text { siswa atas } \\
\text { keterampilan } \\
\text { sosial- } \\
\text { emosional } \\
\text { guru }\end{array}$ & 0,093 & 0,016 & 5,796 & 0,000 \\
\hline
\end{tabular}

\section{Diskusi}

Hasil penelitian menunjukkan bahwa persepsi siswa atas keterampilan sosialemosional guru memiliki peran yang positif terhadap regulasi emosi siswa sekolah inklusi. Hal tersebut didukung oleh penelitian Breeman dkk. (2015) yang menjelaskan bahwa keterampilan emosional yang dimiliki siswa merupakan hasil dari adanya penilaian yang positif terhadap gurunya. Menurut Denham, Bassett, dan Zinsser (2012) regulasi emosi merupakan salah satu bagian dari keterampilan emosi. Selain itu, penilaian positif siswa terhadap gurunya merupakan bagian dari persepsi siswa atas keterampilan sosial-emosional guru. Ketika siswa menilai keterampilan sosial-emosional gurunya dengan positif maka hal tersebut berkaitan dengan peningkatan keterampilan regulasi emosinya. Prewett, Bergin, dan Huang (2019) dalam penelitiannya menjelaskan ketika siswa menilai gurunya memberi dukungan sosialemosional seperti peduli dan membantu, maka siswa akan merasa bahwa dia memiliki kualitas hubungan yang baik dengan guru.

Kualitas hubungan yang baik dengan guru tersebut berkaitan dengan rendahnya perilaku menyimpang yang dilakukan siswa (Prewett dkk., 2019). Breeman dkk. (2015) menjelaskan bahwa siswa yang membentuk hubungan yang positif dengan guru menunjukkan penyesuaian sosial, emosional dan perilaku yang positif. Keterikatan antara guru dan siswa dianggap akan menciptakan rasa percaya dari siswa kepada guru. Siswa akan cenderung untuk melakukan apa yang dilakukan guru karena siswa menganggap bahwa guru merupakan orang yang 


\section{RAHMAWATI \& SAPTANDARI}

dipercaya dan memiliki pengaruh bagi siswa. Guru sebagai orang dewasa juga dianggap akan memberi contoh yang benar. Bandura (dalam Santrock, 2015) mengungkapkan bahwa seorang individu mempelajari perilaku, pikiran, dan perasaannya melalui pengamatan dari perilaku orang lain. Dalam teori modeling dijelaskan bahwa seseorang akan belajar tentang sesuatu dengan cara mengobservasi lalu meniru atau mengimitasi atas apa yang sudah dilakukan orang lain (Santrock, 2015). Siswa yang memiliki hubungan baik dengan guru akan menciptakan intensitas interaksi yang lebih tinggi.

Intensitas interaksi yang tinggi menciptakan pengalaman yang lebih banyak bagi siswa untuk melakukan observasi atas apa yang dilakukan guru dalam menyikapi keberagaman di sekolah inklusi. Siswa mempelajari bagaimana cara guru untuk memperhatikan temannya yang memiliki beragam keunikan. Saarni (dalam Saptandari, 2019) menjelaskan bahwa seseorang yang terampil secara sosial-emosional berkaitan dengan keterampilan regulasi emosinya. Hal tersebut membuktikan bahwa guru dengan keterampilan sosial-emosional yang tinggi akan memberikan contoh tentang keterampilan regulasi emosi kepada siswa khususnya tentang bagaimana untuk menyikapi keberagaman yang ada di sekolah inklusi. Guru akan menunjukkan kepada siswa cara mengatur emosi supaya tidak menciptakan konflik dengan teman karena adanya perbedaan. Siswa pun akan meniru dan mempelajari untuk menciptakan keterampilan regulasi emosi bagi dirinya.

Kualitas hubungan yang baik dengan guru juga didukung dengan adanya keterikatan antara siswa terhadap lingkungan kelas yang memberi pengalaman emosi positif bagi siswa (Macklem, 2008). Respon emosi guru yang positif berkaitan dengan ekspresi positif siswa dan keterampilan regulasi emosinya (Denham dkk., 2012). Siswa terbukti menunjukkan ekspresi emosi positif saat memberi tahu peneliti bahwa kelasnya memiliki siswa yang beragam. Hal itu ditunjukkan saat siswa menjelaskan bahwa dia memiliki beberapa teman yang perlu bantuan tambahan karena temannya tersebut berkebutuhan khusus. Siswa tersebut memberi tahu secara langsung dengan mendekat kepada peneliti. Hal tersebut juga menunjukkan bahwa siswa sudah mengerti bagaimana untuk menunjukkan perasaan empatinya terhadap teman. Siswa sudah belajar bagaimana untuk mengekspresikan dan mengungkapkan perasaan emosinya 
dengan tepat tanpa menyakiti hati. Sikap tersebut pun akan mengarah untuk tidak timbulnya konflik antar teman.

Guru dengan keterampilan sosial dan emosional yang baik mengerti cara untuk meregulasi emosi dan perilakunya serta mengerti bagaimana cara untuk mengatur hubungan dengan orang lain (Jennings \& Greenberg, 2009). Hal tersebut ditunjukkan saat pengambilan data penelitian yaitu guru meminta siswa untuk bersikap sopan dan mengikuti instruksi yang diberikan oleh peneliti. Guru juga meminta siswa untuk saling membantu jika ada teman lain yang kesulitan. Berdasar pesan dari guru tersebut siswa pun menunjukkan sikap yang kooperatif bahkan antar teman saling mengingatkan dan menegur untuk bersikap tenang dan mengikuti instruksi. Siswa juga saling membantu jika temannya ada yang masih kurang paham saat kegiatan penelitian berlangsung. Masing-masing siswa pun saling menghargai dalam proses pengerjaan tanpa memojokkan temannya yang masih kesulitan untuk mengikuti kegiatan penelitian. Beberapa hal tersebut menunjukkan bahwa siswa sudah mampu mengekspresikan emosinya dengan tepat untuk menghindari perdebatan saat berinteraksi dengan teman. Siswa juga sudah mengerti jika masing- masing temannya memiliki tingkat pemahaman yang berbeda sehingga antar teman bisa saling peduli. Siswa pun dapat langsung membantu antar teman tanpa diminta peneliti. Sesuai dengan penjelasan Jennings dan Greenberg (2009) bahwa guru mempengaruhi siswa tidak hanya melalui apa yang telah diajarkan tetapi juga tentang bagaimana cara guru untuk mencontohkan bentuk sosial-emosional dan pengelolaan kelas kepada siswa. Proses pemberian contoh secara langsung tersebut dianggap lebih efektif dalam proses pembelajaran keterampilan emosi pada siswa sekolah dasar. Siswa menjadi tahu kapan dan bagaimana dia harus merasakan dan mengekspresikan emosinya berdasar contoh yang sudah diberikan oleh guru.

Hasil penelitian ini menunjukkan bahwa persepsi siswa atas keterampilan sosial-emosional guru cenderung pada kategori sedang. Selain itu, regulasi emosi siswa juga cenderung pada kategori sedang. Guru memang memiliki peran yang sangat penting dalam mengajarkan dan memodelkan keterampilan emosionalnya kepada siswa (Jennings \& Greenberg, 2009). Guru dapat dengan sengaja atau tidak sengaja melatih siswanya tentang cara mengatur atau meregulasi emosi (Denham dkk., 2012). Guru 
yang secara tidak sengaja mengajarkan tentang keterampilan emosi saat proses belajar mengajar perlu untuk memperhatikan tingkat pemahaman siswa. Siswa sekolah dasar cenderung belum bisa memahami pelajaran yang diberikan secara implisit oleh guru saat proses pembelajaran. Siswa sekolah dasar berada pada tahap perkembangan kognitif operasional konkret atau menuju operasional formal.

Partisipan pada penelitian ini dominan merupakan siswa berusia sebelas tahun yang berarti mereka masih berada pada tahap operasional konkret. Pada tahap operasional konkret di usia tujuh hingga sebelas tahun ini anak-anak melakukan sesuatu dengan melibatkan objek dan mereka dapat berpikir secara logis ketika hal tersebut diterapkan pada contoh yang spesifik atau konkret (Santrock, 2015). Hal tersebut membuktikan bahwa siswa akan cenderung tidak paham jika guru memberi pelajaran yang secara implisit atau tidak sengaja membahas tentang cara mengatur emosi untuk menghindari konflik ketika berkegiatan dengan teman dari latar belakang yang berbeda. Kurangnya pemahaman dari siswa dapat berakibat pada sikap siswa untuk mengabaikan tujuan pelajaran yang diberikan guru dalam menghargai keberagaman di sekolah inklusi.
Ketika hal tersebut diabaikan maka siswa pun juga tidak akan mendapat hasil yang sebenarnya diharapkan oleh guru.

\section{Kesimpulan}

Berdasarkan penelitian yang dilakukan pada 109 siswa di sekolah inklusi dengan rentang usia antara 9-13 tahun ditemukan bahwa terdapat peran yang positif mengenai persepsi siswa atas keterampilan sosialemosional guru terhadap regulasi emosi siswa sekolah inklusi. Semakin tinggi tingkat persepsi siswa atas keterampilan sosialemosional guru maka semakin tinggi pula regulasi emosi siswa. Hasil tersebut sesuai dengan hipotesis dan tujuan yang diajukan dalam penelitian ini.

Saran untuk penelitian selanjutnya dapat menambah subjek penelitian sehingga hasil dari penelitian ini bisa digeneralisir dan diajukan kepada Dinas Pendidikan maupun Pemerintah Kota Yogyakarta untuk membantu memaksimalkan program sekolah inklusi. Peneliti juga menyarankan untuk menambah variabel lain sehingga dapat memperkaya dan memperkuat hasil penelitian.

Secara praktis, penelitian ini dapat memberi pemahaman bagi guru di sekolah inklusi bahwa persepsi siswa atas 
keterampilan sosial-emosional guru dapat memberi dampak pada perkembangan keterampilan regulasi emosi siswa. Oleh karena itu, peneliti menyarankan supaya pihak sekolah dapat memfasilitas kegiatan pelatihan untuk mengembangkan keterampilan sosial-emosional guru.

\section{DAFTAR PUSTAKA}

Anonim. (2019). UPT layanan disabilitas bidang pendidikan dan resource centre Kota Yogyakarta, quo vadis? [Go.id]. Dinas Pendidikan Kota Yogyakarta.

https://pendidikan.jogjakota.go.id/det ail/index/7988

Armstrong, F. (Ed.). (2008). Inclusive Education. In Key issues for teaching assistants: Working in diverse and inclusive classrooms (p. 176). Routledge.

Bowie, B. H. (2010). Understanding the Gender Differences in Pathways to Social Deviancy: Relational Aggression and Emotion Regulation. Archives of Psychiatric Nursing, 24(1), 27-37.

https://doi.org/10.1016/j.apnu.2009.04. 007

Breeman, L., Wubbles, T., van, L. P. A. C., Verhulst, F. C., van, der E., Maras, A., Hopman, J. A. B., \& Tick, N. T. (2015). Teacher characteristic, social classroom relationships, and children's social, emotional, and behavioral classroom adjustment in special education. Journal of School Psychology, 53, 87-103. http://dx.doi.org/10.1016/j.jsp.2014.11. 005

Budiarti, N. D., \& Sugito, S. (2018). Implementation of Inclusive
Education of Elementary Schools: A Case Study in Karangmojo SubDistrict, Gunungkidul Regency. Journal of Education and Learning (EduLearn), 12(2), 214. https://doi.org/10.11591/edulearn.v12i 2.8727

Callear, A., Harvey, S. T., \& Bimler, D. (2017). Understanding the structure of children's emotion-regulation strategies. International Journal of Behavioral Development, 41(3), 456-462. https://doi.org/10.1177/0165025416647 525

Chan, T., \& Yuen, M. (2015). Inclusive Education In An International School: A Case Study From Hong Kong. International Journal of Special Education, 30(3), 12.

Creswell, J. W. (2012). Educational research: Planning, conducting, and evaluating quantitative and qualitative research (4th ed). Pearson.

Denham, S. A., Bassett, H. H., \& Zinsser, K. (2012). Early Childhood Teachers as Socializers of Young Children's Emotional Competence. Early Childhood Education Journal, 40(3), 137143. https://doi.org/10.1007/s10643012-0504-2

Field, A. P. (2009). Discovering statistics using SPSS: And sex, drugs and rock " $n$ " roll (3rd ed). SAGE Publications.

Graziano, P. A., Reavis, R. D., Keane, S. P., \& Calkins, S. D. (2007). The role of emotion regulation in children's early academic success. Journal of School Psychology, 45(1), 3-19. https://doi.org/10.1016/j.jsp.2006.09.00 2

Gross, J. J. (2014). Handbook of Emotion Regulation, Second Edition (Second). The Guildford Press.

Hadi. (2015). Metodologi Riset. Pustaka Pelajar. 
Harvey, S. T., Bimler, D., Evans, I. M., Kirkland, J., \& Pechtel, P. (2012). Mapping the classroom emotional environment. Teaching and Teacher Education, 28(4), 628-640. https://doi.org/10.1016/j.tate.2012.01.0 05

Jennings, P. A., \& Greenberg, M. T. (2009). The Prosocial Classroom: Teacher Social and Emotional Competence in Relation to Student and Classroom Outcomes. Review of Educational Research, 79(1), 491-525. https://doi.org/10.3102/0034654308325 693

Karababa, A. (2020). The relationship between trait anger and loneliness among early adolescents: The moderating role of emotion regulation. Personality and Individual Differences, 159, 109856. https://doi.org/10.1016/j.paid.2020.109 856

Kelsey, C., Zeman, J., \& Dallaire, D. (2017). Emotion Correlates of Bullies, Victims, and Bully-Victims in African American Children. Journal of Black Psychology, 43(7), 688-713. https://doi.org/10.1177/0095798416680 719

Macklem, G. L. (2008). Practitioner's Guide to Emotion Regulation in School-Aged Children. Springer US. https://doi.org/10.1007/978-0-38773851-2

Pelled, L. H., Eisenhardt, K. M., \& Xin, K. R. (1999). Exploring the Black Box: An Analysis of Work Group Diversity, Conflict, and Performance.
Administrative Science Quarterly, 44(1), 1. https://doi.org/10.2307/2667029

Prewett, S. L., Bergin, D. A., \& Huang, F. L. (2019). Student and teacher perceptions on student-teacher relationship quality: A middle school perspective. School Psychology International, 40(1), 66-87. https://doi.org/10.1177/0143034318807 743

Puri, M., \& Abraham, G. (2004). Why Inclusion? In Handbook of Inclusive Education for Educators, Administrators, and Planners (p. 310). Sage Publications Ltd.

Santrock, J. W. (2015). Life-span development (Fifteenth edition). McGraw-Hill.

Saptandari, E. (2019). Understanding Indonesian Primary School Teachers Social-Emotional Practice. Massey University.

Sutton, R. E., \& Wheatley, K. F. (2003). Teachers' Emotions and Teaching: A Review of the Literature and Directions for Future Research. Educational Psychology Review, 32.

UNICEF. (2017). Inclusive EducationIncluding children with disabilities in quality learning: What needs to be done? Inclusive Education, 4.

Utantoro, A. (2016). Yogyakarta bertekad jadi Kota Inklusi [..Com]. Media Indonesia. https://mediaindonesia.com/read/deta il/77714-yogyakarta-bertekad-jadikota-inklusi

Wulandari, A. (2018). Hubungan antara Kualitas Relasi Guru-Siswa dan Regulasi Emosi pada Anak Usia 9-11 tahun. Universitas Sanata Dharma. 